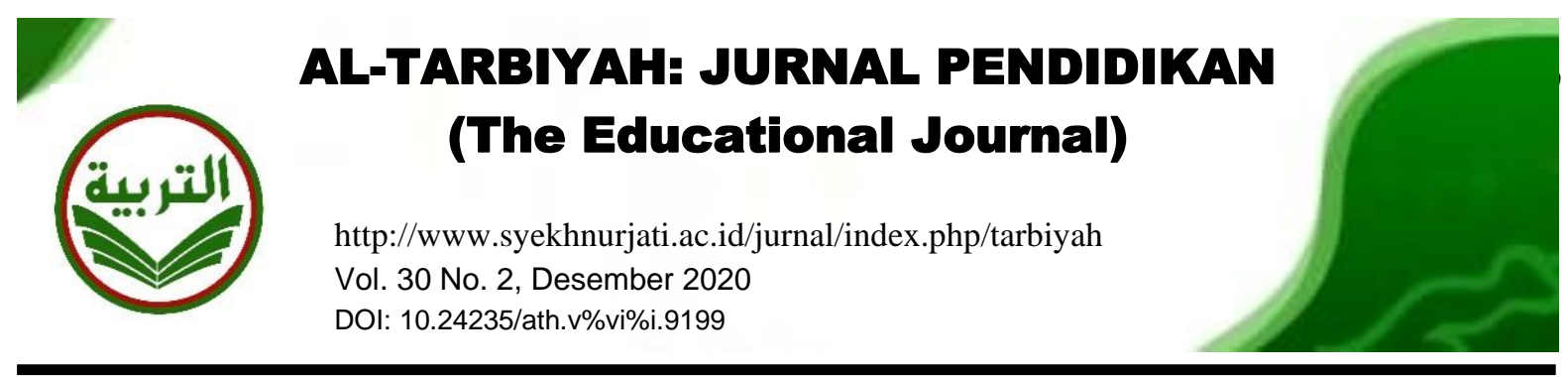

\title{
TAHAP PENGGUNAAN MEDIA BRAIL TEXT BAGI SISWA TUNANETRA DALAM PEMBELAJARAN AL-QUR'AN DI SLBA TUNANETRA PAYAKUMBUH
}

\author{
Mezy Ramadhan Putra', Risdoyok ${ }^{2}$ \\ ${ }^{1}$ Pendidikan Agama Islam, IAIN Bukittinggi \\ ${ }^{2}$ Pendidikan Agama Islam, IAIN Bukittinggi \\ e-mail: risdoyokjournals@gmail.com
}

\begin{abstract}
Abstrak
Pemahaman tentang penggunaan media Braille text dan tahapan penggunaanya sangat perlu dipelajari sampai tuntas bagi siswa baru. Jika siswa tidak mempelajarinya dengan baik, hal tersebut akan berdampak pada tahap selanjutnya. Hal ini dibuktikan dengan banyaknya siswa yang mengalami kesulitan dalam membaca Al-Qur'an Braille sehingga terjadi hambatan dalam proses pembelajaran maupun membaca Al-Qur'an. Tujuan penelitian ini adalah untuk mengetahui tahapan pengunaan media Braille text dalam pembelajaran Al-Qur'an di SLB-A Tunanetra Payakumbuh. Metode penelitian menggunakan pendekatan kualitatif dengan data bersumber dari observasi, wawancara, serta dokumentasi. Metode analisis data digunakan dalam penelitian ini adalah metode kualitatif deskriptif. Hasil peneletian ini menunjukkan bahwa tata cara penggunaan media Braille text sangat penting untuk dipelajari oleh siswa baru. Siswa mempelajari cara membedakan bagian yang timbul dan yang tidak timbul, mengenal posisi masing-masing titik, dan membuat berbagai jenis titik. Siswa belajar membuat titik penuh, tiga titik yang terletak di seluruh kanan pada posisi menulis (titik, satu, dua dan tiga), tiga titik yang terletak di sebelah kiri pada posisi menulis (titik empat, lima, dan enam, dua titik yang terletak pada bagian atas (titik satu dan empat), titik yang terletak pada bagian tengah (titik dua dan lima), dan titik yang terletak pada bagian bawah (titik tiga dan enam). Selanjutnya siswa mulai berlatih menulis huruf, suku kata, kata, dan kalimat sederhana. Kendala yang terjadi adalah guru merasa kelelahan dalam pelaksanaannya di kelas dan dalam pembuatan RPP guru juga merasa kualahan. Selain itu tenaga pendidik di SLB-A Tunanetra Payakumbuh juga kurang.
\end{abstract}

Kata Kunci: Media, Braille Text, Pembelajaran Al-Qur'an.

\begin{abstract}
Understanding the use of Braille text media and its implementation stages really needs to be studied thoroughly by news students. If students do not learn them well, the next stages will be affected. It is proven by many of the students that have difficulties in reciting the Braille Qur'an so there are obstacles in the learning process and Qur'an recitation. The purpose of this study was to find out the stages of using Braille text media in Qur'an learning at SLB-A for the blind Payakumbuh. The research method used a qualitative approach with data obtained from observations, interviews, and documentation. The data analysis method used in this study was descriptive qualitative method. The results of this research indicate that the procedure for using Braille text media is very important to be
\end{abstract}


learned by new students. Students learn how to distinguish the raised and unraised parts, to recognize the positions of each dot and to make various types of dots. Students learn how to make full dots, three dots located on the right side of the writing position (dot one, two, and three); three dots located on the left side of the writing position (dot four, five, and six); two dots located on top (dot one and four); dots located in the middle (dot two and five); and dots located at the bottom (dot three and six). Then students start to practice writing letters, syllables, words and simple sentences. The obstacle was teachers felt exhausted in its implementation in the classroom and the development of lesson plans was overwhelmed. Besides that, there was a shortage of teachers at SLB-A for the blind Payakumbuh.

Keywords: Media, Braille Text, Al-Qur'an Learning.

\section{PENDAHULUAN}

Pendidikan adalah upaya sadar dan sistematis untuk menciptakan suasana belajar dan proses pembelajaran agar peserta didik dapat secara aktif mengembangkan potensi dirinya dan memiliki kekuatan spiritual keagamaan, pengendalian diri, kepribadian, kebijaksanaan, moralitas yang luhur, dan keterampilan yang diperlukan dirinya, masyarakat, bangsa, dan negara.

Tujuan pendidikan nasional adalah harapan seluruh rakyat Indonesia, khususnya siswa berkebutuhan khusus. UU Sistem Pendidikan Nasional No. 20 Tahun 2003, Bab 4 Pasal 5 ayat 2, mengatur bahwa warga negara yang memiliki hambatan fisik, emosional, intelektual, dan/atau sosial berhak memperoleh pendidikan khusus (Depdiknas, 2003).

Peraturan tersebut merupakan upaya strategis dan holistik untuk membuktikan bahwa kesempatan pendidikan yang berkualitas diberikan dan berlaku untuk semua (Education for All) tanpa diskriminasi. Undang-undang ini juga memberikan hak kepada siswa tunanetra untuk mendapatkan pendidikan yang berkualitas.

Dalam Undang-Undang Sistem Pendidikan Nasional Nomor 20, Pasal 32 ayat 1 disebutkan bahwa pendidikan khusus adalah tentang kesulitan fisik, emosi, mental, sosial, atau potensi kecerdasan dan kekhususan (Depdiknas, 2003).

Pendidikan merupakan salah satu produk terpenting bagi semua anak, tidak hanya bagi anak biasa, tetapi juga bagi anak berkebutuhan khusus. Anak berkebutuhan khusus, seperti anak biasa, juga memerlukan pendidikan untuk mendidik terutama anak cerdas, yang setara dengan sekitar 2,2 dari seluruh anak usia sekolah, Hanya $0,43 \%$ anak berkebutuhan khusus yang mendapatkan pelayanan (Atmaja, 2018).

Penderita penyakit apapun, baik yang lahir dalam keadaan normal maupun berkebutuhan khusus, sebenarnya memiliki potensi yang luar biasa. Allah SWT berfirman dalam Al-Qur'an:

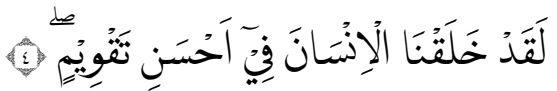

Terjemahan: Sungguh, Kami telah menciptakan manusia dalam bentuk yang sebaik-baiknya (Qs At-Tin:4).

Buya Hamka (dalam Pratiwi, 2021) menafsirkan bahwa sebaik-baik bentuk yang disampaikan dalam ayat ini bukan hanya berkaitan dengan persoalan kondisi fisik, tetapi meliputi seluruh potensi yang Allah berikan baik potensi lahir maupun batin. Melalui potensi inilah setiap manusia sesungguhnya dapat meraih keistimewaan dan kemuliaan dirinya manakala potensi itu dapat dikelola dengan 
baik dan benar. Namun sebaliknya, jika potensi tersebut tidak diasah dan digunakan dengan sebaik-baiknya justru itulah yang membuat manusia jatuh dalam kehinaan. Potensi merupakan bekal yang dapat digunakan manusia untuk menghadapi dan mengatasi setiap persoalan hidupnya dan tidak seorang pun manusia yang diciptakan Allah tanpa potensi yang memadai. Itulah sebabnya dalam ayat lain kembali ditegaskan:

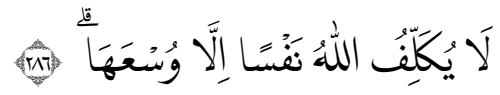

Terjemahan: Allah tidak membebani seseorang melainkan sesuai dengan kesanggupannya. (Qs Al-Baqarah:286).

Maka, hadirnya anak berkebutuhan khusus bukanlah aib atau petaka yang harus ditutupi apalagi disesali karena mereka pun memiliki potensi yang tidak kalah dibandingkan dengan yang lain. Mereka juga bukan makhluk kelas dua. Mereka juga sejajar dengan anak normal serta memiliki hak yang sama. Oleh karena itu, membantu agar mereka mampu menggali serta mengembangkan potensi yang mereka miliki merupakan hal yang penting (Setiarani \& Suchyadi, 2018).

Hal ini membuktikan bahwa anak berkebutuhan khusus dapat bekerja sama dengan baik dengan anak normal jika kebutuhan anak berkebutuhan khusus diperhatikan dengan baik dan pengawas memberikan jenis bimbingan belajarnya sendiri. Anak berkebutuhan khusus dalam hal ini khususnya tunanetra memiliki bakat yang sama dan memiliki IQ yang sama dengan anak biasa (Smart, 2010).
IQ rendah sering dianggap cukup untuk menjelaskan cacat perkembangan anak dalam hal ini. Tentu saja, ini tidak benar-benar tepat. Tuhan menciptakan manusia dengan potensi yang sama, sehingga potensi hanya tergantung pada upaya manusia untuk menumbuhkan dan memanfaatkannya (Smith, 2006)

Siswa tunanetra memiliki berbagai kondisi, diantaranya kurangnya perhatian dan pelayanan yang optimal terkait dengan fasilitas belajar. Selain itu, sekolah inklusi memiliki banyak masalah pembelajaran, terutama bagi siswa penyandang disabilitas dan disabilitas intelektual. Tentu saja kemampuan berkomunikasi antara siswa difabel dengan siswa reguler sangat berbeda. Istilah slow learner sering digunakan untuk anak-anak yang tidak lambat dalam belajar.

Kelas untuk siswa penyandang cacat didasarkan pada pemahaman kebutuhan siswa-siswa ini. Konseling bagi siswa penyandang disabilitas di sekolah inklusi memerlukan pengamatan yang seksama terhadap kelemahan dan kelebihan mereka. Siswa penyandang disabilitas diajar dan berinovasi seperti siswa reguler lainnya. Jika pembimbing dapat mendukung keberhasilan pembelajaran, termasuk informasi dan pendidikan yang penting berdasarkan kondisi individu siswa, siswa akan dapat menunjukkan kemampuan yang sangat baik.

Anak berkebutuhan khusus membutuhkan perlakuan yang sama dengan anak lainnya, kecuali dalam hal pendidikan. Jenis anak berkebutuhan khusus antara lain: (1) anak tunanetra, (2) 
anak tunarungu, (3) anak tunagrahita (4) anak tunadaksa, (5) tunalaras dan (6) tunaganda (Efendi, 2006).

Peneliti menemukan beberapa kendala dalam proses pembelajaran bagi anak berkebutuhan khusus, terutama anak tunanetra. Dalam perlaksanaan pembalajaran di kelas, guru merasa kesulitan dalam mengimplementasikan pembelajaran Al-Qur'an Braile pada saat pembelajaran. Beberapa alasan melatarbelakangi hal tersebut. Pertama, anak tunanetra cenderung kurang memperhatikan pelajaran. Kedua, kurangnya waktu bagi anak tunanetra dalam belajar Al-Qur'an bertuliskan Braille. Selain itu, anak tunanetra lebih cenderung mengunakan media perekam sebagai media pembalajaran seperti tape recorder. Seharusnya, dalam proses pembelajaran, siswa mampu membaca AlQur'an Braille dengan benar karena sejatinya anak tunanetra identik dengan pemahaman terhadap tulisan Braille (Afif et al., 2021).

Selanjutnya penulis juga menemukan kesulitan pada siswa pada saat membaca Al-Qur'an Braille di kelas. Satu siswa tunanetra yang peneliti wawancarai mengatakan bahwa media pembelajaran cukup minim sehingga siswa tunanetra sulit untuk belajar. Selain itu, ketika guru menjelaskan di kelas, suara guru tersebut kurang terdengar. Ketersediaan mediamedia pembelajaran yang berkaitan, seperti Braille text, Papan Paku, Papan Kabe, dan Riqlet yang biasanya digunakan untuk media belajar siswa tunanetra minim. (Arif, Kalimatusyaroh \& Setyawati, 2021).
Sehingga melihat fakta-fakta yang terjadi sebelumnya dan beberapa sumber terkait yang menjelaskan permasalahan yang sama, maka peneliti ingin memperkenalkan media belajar berupa Braille text pada anak tunanetra. Dengan hal ini diharapkan siswa dapat mahir dalam membaca Al-Qur'an Braille text. Pada hakikatnya anak tunanetra wajib bisa membaca dan menulis Braille. Oleh karena itu, peneliti tertarik untuk mengkaji secara terperinci terkait dengan judul Tahap Penggunaan Media Braille text bagi Siswa Tunanetra dalam Pembelajaran Al-Qur'an di SLBA Tunanetra Payakumbuh.

\section{METODE PENELITIAN}

Penelitian ini mengunakan pendekatan kualitatif deskriptif dengan tujuan untuk mengetahui fakta dari fenomena-fenomena yang terjadi di lapangan ketika penelitian dilakukan baik itu fenomena alamiah maupun rekayasa manusia (Risdoyok, 2021). Penelitian ini dilaksanakan di SLBA Tunanetra Payakumbuh. Menurut peneliti, tempat tersebut sangat tepat untuk menjadi lokasi penelitian dengan permasalahan yang dibahas. Selain pertimbangan lokasi penelitian yang tepat, di SLBA Tunanetra Payakumbuh, jangkauan informasi, kesedian tenaga, waktu, maupun efesiensi biaya cukup mudah diperoleh. Waktu yang dibutuhkan untuk penelitian ini berkisar empat bulan terhitung dari bulan Maret 2021 sampai dengan Juli 2021.

Jenis data yang digunakan merupakan data primer dan sekunder. Data primer adalah data yang didapatkan dari sumber utama, baik individu maupun 
kelompok yang diperoleh melalui wawancara. Data sekunder merupakan data yang telah diolah dan disajikan oleh pihak lain. Data sekunder didapatkan melalui data yang berupa dokumen atau laporan administrasi yang berkaitan dengan penggunaan Media Braille text dalam pembelajaran Al-Qur'an (Maria et al., 2021).

Penelitian ini dilakukan dengan pengamatan secara langsung dan apa adanya sesuai dengan apa yang terjadi di lapangan saat peneliti mengambil data. Hal tersebut sesuai dengan tujuan penelitian ini yaitu untuk mengetahui bagaimana tahapan pengunaan media Braille text oleh guru dalam pembelajaran Al-Qur'an Braille di SLBA Tunanetra Payakumbuh serta upaya apa saja yang dilakukan oleh guru dalam mempermudah peserta didiknya belajar AlQur'an Braille. Sumber informasi diperoleh dari kepala sekolah, guru-guru serta pihak-pihak terkait lainnya di SLBA Tunanetra Payakumbuh. Agar tujuan dari penelitian ini tercapai, baik dari keadaan serta pendapat informan tentang tahaptahap penggunaan media Braille text di SLBA Tunanetra Payakumbuh, peneliti mencari sumber relevan dan membandingkan hasilnya dengan hasil yang diperoleh dari wawancara serta dokumen yang didapatkan pada saat penelitian.

\section{HASIL DAN PEMBAHASAN}

\section{Tahapan Penggunaan Media Braille Text}

Pengunaan media Braille text dilakukan dengan menekan titik-titik dari sisi bawah atau belakang sehingga titik- titik tersebut muncul ke sisi atas atau depan membentuk huruf-huruf Braille yang digunakan. Seperti halnya reglet, menulis dengan Braille text ini juga dimulai dari sebelah kanan, dan untuk membacanya juga dimulai dari sebelah kiri. Menulis dengan mengunakan Braille text ini juga dikenal dengan menulis secara negatif dan untuk membacanya juga dikenal dengan membaca secara positif.

Media secara umum merupakan suatu alat atau sejenisnya yang dapat dipergunakan sebagai pembawa pesan dalam suatu kegiatan pembelajaran. Pesan yang dimaksud adalah materi pelajaran, dimana keberadaan media tersebut dimaksudkan agar pesan dapat lebih muda dipahami dan dimengerti oleh siswa. Media adalah perantara atau pengantar. Dalam pembelajaran media adalah segala sesuatu yang digunakan untuk menyalurkan pesan dan merangsang terjadinya proses belajar pada siswa Sadiman, 2011).

Menurut Gagne (dalam Gayatri \& Ningtyas, 2017, p. 92) "media adalah berbagai jenis komponen dalam lingkungan siswa yang dapat merangsangnya untuk belajar", sedangkan Asosiasi Pendidikan Nasional (National Education Association/ NEA) (dalam Sapriyah, 2019) mendefinisikan media sebagai berbagai jenis alat komunikasi baik cetak maupun 'audio visual'. Media adalah segala sesuatu yang dapat digunakan untuk menyalurkan pesan dari pengirim ke penerima sehingga dapat merangsang pikiran, perasaan, perhatian dan minat serta 


\section{Cara Pengunaan Media Braille Text}

Cara penggunaan media Braille text ini adalah dengan menekan titik-titik dari sisi bawah atau belakang sehingga titiktitik tersebut muncul ke sisi atas atau depan membentuk huruf-huruf Braille yang digunakan. Seperti halnya reglet, untuk menulis dengan Braille text ini juga dimulai dari sebelah kanan dan untuk membacanya juga dimulai dari sebalah kiri. Menulis dengan mengunakan Braille text ini juga dikenal dengan menulis secara negatif, dan untuk membacanya juga dikenal dengan membaca secara positif (Ayu, 2010).

Berdasarkan wawancara dengan guru, berikut cara menggunakan Braille text. Pertama, tekan semua titik Braille (cembung) pada permukaan baca hingga tidak ada titik yang menonjol. Kedua, papan dibalik dengan posisi menulis, semua titik Braille (datar) dalam keadaan menonjol. Ketiga, tekan titik-titik Braille yang hendak ditulis. Setelah selesai menulis (menekan), balikan papan ke posisi membaca. Titik Braille yang menonjol di papan merupakan posisi yang dibaca atau diraba (Rahmayenti, Komunikasi Pribadi, 6 Maret 2021).

\section{Tahap-Tahap Penggunaan Media Braille Text}

Ada beberapa tahap yang harus dilakukan dalam latihan menggunakan media Braille text. Tahapan tersebut meliputi: (a) membedakan bagian yang timbul dan yang tidak timbul; (b) mengenal posisi masing-masing titik; (c) membuat titik penuh; (d) membuat tiga titik yang terletak di seluruh kanan pada posisi menulis, yaitu titik satu,dua dan tiga; (e) membuat tiga titik yang terletak di sebelah kiri pada posisi menulis, yaitu titik empat, lima, dan enam; (f) membuat dua titik yang terletak pada bagian atas, yaitu titik satu dan empat; (g) membuat titik yang terletak pada bagian tengah,yaitu titik dua, dan lima; (h) membuat titik yang terletak pada bagian bawah, yaitu titik tiga dan enam; (i) mulai latihan menulis huruf; (j) latihan menulis suku kata, lalu menulis kata; dan (k) menulis kalimat sederhana. Setelah anak bisa menggunakan media Braille text, barulah dilanjutkan ke reglet (Ayu, 2010).

Berdasarkan beberapa pendapat di atas, dapat diambil kesimpulan bahwa media adalah segala sesuatu yang dapat digunakan seseorang dalam menyampaikan pesan kepada penerima pesan. Dalam pembelajaran, media adalah segala sesuatu yang ada di sekitar siswa yang dapat dijadikan sebagai sarana untuk menyampaikan pesan kepada siswa. Penyampaian pesan dalam hal ini adalah materi pembelajaran. Peneliti juga mengkaji secara berurutan, mulai dari kegiatan pendahuluan, kegiatan inti, dan kegiatan penutup dalam proses pembelajaran.

\section{(1) Kegiatan Pendahuluan}

Kegiatan pertama adalah
pengenalan kelompok belajar yang
bertujuan untuk memotivasi dan menarik
perhatian siswa untuk berpartisipasi aktif
dalam proses pembelajaran (Majid,
2012) Dalam kegiatan ini, guru
mempersiapkan siswa secara mental dan


fisik untuk berpartisipasi dalam proses pembelajaran.

Kemudian melalui doa bersama, guru mengisi kehadiran dan memulai pembelajaran dengan mengaitkan kehidupan sehari-hari dengan topik yang dipelajari. Guru meminta siswa untuk membaca surat-surat pendek yang mereka pelajari sebelum mereka mulai belajar. Guru kemudian mulai menjelaskan tujuan pembelajaran.

Berdasarkan data yang didapatkan dari wawancara dengan Guru 1, guru tersebut menyebutkan bahwa dalam kegiatan pendahuluan pertama guru tidak membuat RPP. Hal tersebut dikarenakan guru mengalami kesulitan dalam menyesuaikan beberapa tingkatan siswa mulai dari kelas 1-9 yang ada dalam satu lokal. Selain itu, adanya masalah motivasi siswa. Guru 1 selalu memberikan motivasi pada siswa sebelum pelajaran dimulai. Selanjutnya, adanya masalah dalam menentukan tema. Guru 1 selalu menentukan tema sebelum pelajaran dimulai agar pelajaran diterima siswa dengan terarah dan baik, sehingga tercapai tujuan yang diharapkan (Rahmayenti, Komunikasi Pribadi, 6 Maret 2021).

\section{(2) Kegiatan Inti}

Kegiatan inti merupakan proses belajar untuk mencapai kemampuan dasar. Kegiatan pembelajaran bersifat interaktif, menggairahkan, menghibur, bermanfaat, memotivasi untuk berpartisipasi aktif, dan sesuai dengan bakat, minat, perkembangan fisik dan psikologis siswa, inisiatif, kreativitas dan kemandirian. Kegiatan ini dilakukan secara sistematis (Majid, 2012)

Pada kegiatan inti, guru menyampaikan materi pembelajaran $\mathrm{Al}-$ Qur'an dengan menggunakan metode dan media yang disesuaikan dengan karakteristik siswa dan mata pelajaran. Agar siswa lebih memahami materi tersebut, guru harus mengulang-ulang penjelasan materi yang diajarkan. Selain itu, untuk mengetahui sejauh mana tingkat pemahaman siswa, guru dianjurkan untuk melakukan interaksi, seperti dengan memberikan tanya jawab kepada siswa tentang materi Al-Qur'an yang diajarkan.

Berdasarkan hasil wawancara dengan Guru 1 yang mengajar mata pelajaran Al-Qur'an Braille text, guru mengatakan bahwa dalam proses pembelajaran, guru juga mengajarakan bagaimana cara mengunakan Braille text, mulai dari membedakan antara bagian titik yang timbul dan yang tidak timbul dan posisi masing-masing titik. Guru 1 juga memberi kesempatan kepada siswa untuk mencoba membuat titik penuh. Selain itu, Guru 1 memperkenalkan kepada siswa cara menulis dari titik bagian kanan dan dari titik bagian kiri tulisan. Setelah itu, Guru 1 memberi latihan kepada siswa untuk mulai mencoba menulis huruf hijaiyah. Kemudian, Guru 1 memberi latihan pada siswa untuk mencoba menulis suku kata, yang dilanjutkan dengan mencoba menulis kalimat. Di akhir, Guru 1 melakukan evaluasi tentang pembelajaran yang sudah dilakukan pada hari itu. Bentuk evaluasi yang diberikan adalah Accepted: November $1^{\text {st }}, 2021$. Approved: December 30 ${ }^{\text {th }}, 2021$. Published: December, 2021 
quiz, soal, dan tanya jawab berkaitan dengan materi yang diajarkan pada hari itu. Selain itu, Guru 1 juga memberikan bimbingan kepada siswa yang masih belum bisa membaca dan menulis Braille (Rahmayenti, Komunikasi Pribadi, 6 Maret 2021).

Berdasarkan hasil wawancara dengan guru lain di SLBA Tunanetra Payakumbuh, terkait tahapan penggunaan Braille text dalam pembelajaran AlQur'an Braille, Guru 2 menyampaikan bahwa anak tunanetra harus bisa membaca dan menulis Braille karena mereka bersekolah di SLB-A khusus tunanetra. Disamping itu, anak tunanetra dituntut untuk bisa membaca dan menulis Braille karena pada hakikatnya huruf Braille merupakan jati diri tunanetra. Menurut Guru 2, akan percuma jika anak yang berkebutuhan khusus (tunanetra) bisa mengunakan alat bantu yang lain seperti laptop, komputer, hp dan sejenisnya, tetapi tidak bisa membaca dan menulis Braille (Erlina, Komunikasi pribadi, 7 Maret 2021).

Kemudian berdasarkan hasil wawancara dengan guru berikutnya (Guru 3) dengan pertanyaan yang sama, peneliti mendapatkan informasi yang sama bahwa semakin terlihat perubahan dari generasi ke generasi. Siswa generasi sebelumnya cenderung banyak bertanya, berkemauan tinggi, dan belum terkontaminasi oleh alat-alat elektronik, sedangkan anak-anak generasi sekarang lebih suka dengan cara yang instan sehingga anak-anak cenderung mengabaikan membaca dan menulis Braille (Ardawanis, Komunikasi Pribadi, 8 Maret 2021).
Disamping peneliti mewawancarai para guru SLBA Tunanetra Payakumbuh, peneliti juga melakukan wawancara dengan beberapa siswa. Menurut Siswa 1, membaca dan menulis Braille sangat perlu bagi siswa karena siswa ingin mampu membaca dan menulis Al-Qur'an sebagaimana anak-anak normal pada umumnya (Zaki, Komunikasi Pribadi, 9 Maret 2021) Siswa lain (Siswa 2) mengatakan hal yang tidak jauh berbeda dengan Siswa 1 bahwa membaca dan menulis Braille perlu bagi siswa karena dia bercita-cita ingin menjadi seorang penghafal Al-Qur'an (Noval, Komunikasi Pribadi, 9 Maret 2021). Selain itu, siswa 3 mengatakan bahwa Al-qur'an Braille sangat perlu dipelajari, karena ini adalah salah satu pelajaran yang sangat penting bagi anak tunanetra, Jika anak tunanetra tidak membaca dan menulis Braille, mereka akan kesulitan untuk memahami Al-Qur'an seutuhnya. Karena anak tunanetra juga ingin seperti anak-anak normal pada umumnya yang bisa membaca, menulis, dan memahami AlQur'an yang baik dan benar (Yahdi, Komunikasi Pribadi, 9 Maret 2021)

Peneliti juga mewawancari salah seorang anak yang telah bisa bergabung dengan anak normal tetapi dia masih tinggal di Asrama SLB-A Tunanetra Payakumbuh. Siswa 4 yang duduk di kelas 12 MAN 2 Payakumbuh mengatakan bahwa belajar membaca dan menulis Al-Qur'an sangat diperlukan. Siswa 4 pernah merasakan menjadi orang yang bisa melihat tetapi karena suatu penyakit tertentu dia menjadi seorang tunanetra. Dia berkeinginan setelah bisa membaca dan menulis Al-Qur'an Braille, 
dia ingin sekali mengajarkannya kepada orang yang senasib dengannya agar mampu membaca sebagai mana dirinya (Fauzan, Komunikasi Pribadi, 9 Maret 2021).

Dari beberapa hasil wawancara di atas, dapat disimpulakan bahwa dalam proses pembelajaran yang terdiri dari kegiatan pendahuluan, inti, dan penutup, guru tetap melakukannya sesuai dengan prosedur, tetapi guru terkendala dalam pembuatan RPP. Kemudian, dalam proses pembelajaran guru mengajarkan semaksimal mungkin tentang cara membaca dan menulis Braille, mulai dari mengenal apa itu Braille sampai dengan tata cara pengunaan Braille text. Guru juga selalu membimbing anak-anak yang kurang pandai membaca dan menulis Braille. Dua guru lainnya juga menyatakan bahwa pelajaran membaca dan menulis Braille sangat perlu dipelajari oleh anak tunanetra.

Selajutnya, dari beberapa hasil wawancara dari siswa, dapat disimpulkan bahwa siswa berkeinginan untuk mempelajari cara membaca dan menulis Braille dengan baik dan benar. Salah satu cara untuk memudahkan siswa membaca dan menulis Braille adalah siswa diajarkan oleh guru bagaimana mempelajari Al-qur'an dengan mengunakan media yang bernama Braille text.

\section{(3)Kegiatan Penutup}

Penutup merupakan kegiatan yang dilakukan untuk mengakhiri aktivitas pembelajaran yang dapat dilakukan dalam bentuk rangkuman atau kesimpulan, penilaian, refleksi, umpan balik, dan tindak lanjut. Sama halnya dengan proses kegiatan penutup untuk siswa normal lainnya, sebelum mengakhiri pembelajaran, guru mengevaluasi sejauh mana materi yang disampaikan dapat dipahami oleh siswa, yakni dengan cara memberikan pertanyaan kepada siswa secara lisan maupun tulisan yang terkait dengan materi Al-Qur'an yang diajarkan. Kemudian, kegiatan diakhiri dengan berdoa (Widjaya, 2012).

Sebagaimana yang disampaikan oleh guru, dalam mengakhiri kegiatan atau penutupan pembelajaran, guru selalu melakukan evaluasi kepada siswa sesuai konteks pembelajaran yang telah dilaksanaan pada hari itu. Hal tersebut dilakukan agar siswa dapat memahami pelajaran yang telah dilakukan dan guru dapat mengetahui tingkat kemampuan siswa (Rahmayenti, Komunikasi Pribadi, 6 Maret 2021)

\section{SIMPULAN}

Dalam tahapan penggunaan media Braille text dalam pembelajaran Al-Qur'an di SLBA Tunanetra Payakumbuh, semua tahapan telah dilakukan, kecuali pembuatan RPP karena siswa dalam satu lokal terdiri dari kelas 1-9 sehingga sulit bagi guru untuk menyesuaikannya. Pengunaan media Braille text dalam pembelajaran Al-Qur'an Braille sangat penting untuk anak yang berada dalam tahap belajar membaca dan menulis AlQur'an Braille supaya anak mampu membaca dan menulis Braille dengan baik dan benar. Cara yang mudah bagi anak tahap awal dalam belajar membaca dan 
menulis Al-Qur'an Braille salah satunya dengan menggunakan media. Media yang lebih mudah bagi anak untuk mengenal posisi titik adalah menggunakan media Braille text karena untuk anak tahap awal, sangat penting untuk mengenal tentang perbedaan antara titik yang timbul dan titik yang tidak timbul, mengenal posisi masing-masing titik, cara menggunakan titik penuh, hingga cara membaca dan menulis Braille. Kemudian, anak juga diajak untuk berlatih menggunakan media Braille text dengan baik dan benar. Pihak sekolah juga merasa perlu tenaga pendidik tambahan yang ahli dalam tahap-tahap penggunaan media Braille text untuk mata pelajaran Al-Qur'an Braille agar keberhasilan siswa dalam membaca dan menulis Al-Qur'an Braille tercapai dengan baik.

\section{DAFTAR PUSTAKA}

Afif, M. A., Salsabila, U. H., Syaifullah, A., \& Hariadi, D. (2021). Metode Pembelajaran Al-Quran Bagi Anak Berkebutuhan Khusus Tunanetra. ISTIGHNA: Jurnal Pendidikan dan Pemikiran Islam, 4(1), 16-24.

Arif, M., Kalimatusyaroh, M., \& Setyawati, N.R. (2021). Optimalisasi Guru Dalam Menumbuhkan Minat Membaca Huruf Braille Pada Siswa Tunanetra. Vox Edukasi: Jurnal Ilmiah Ilmu Pendidikan, 38-57.

Atmaja, J. R. (2018). Pendidikan dan Bimbingan Anak Berkebutuhan Khusus. Bandung: Rosda.

Ayu, M. (2010). Meningkatkan Kemampuan Pra-Menulis Braille Melalui Media Brailtext Bagi Anak Tuna Netra. Universitas Negeri Padang.
Depdiknas. (2003). Undang-undang RI No.20 tahun 2003 tentang Sistem. Pendidikan Nasional. Jakarta: Depdiknas.

Efendi, M. (2006). Pengantar Psikopedagogik Anak Berkelaian. Pt Bumi Aksara.

Gayatri, A. M., \& Ningtyas, S. I. (2017). Peningkatan Minat terhadap Hasil Belajar Peserta Didik melalui Media Permainan Ular Tangga pada Pelajaran Kewirausahaan di Sekolah Menengah Kejuruan (Studi Penelitian Peserta Didik Kelas X di lokasi di Jakarta Timur, Tangerang Selatan, dan Depok). Research and Development Journal of Education, 4(1).

Majid, A. (2012). Belajar Dan Pembelajaran Pendidikan Agama Islam. Remaja Rosdakarya.

Maria, R., Pendidikan, A., \& Padang, U. N. (2021). Edukatif: Jurnal Ilmu Pendidikan Urgensi Perencanaan Strategis Dalam Meningkatkan Pengembangan dan Mutu Pendidikan. 3(5), 2012-2024.

Risdoyok, R., \& Aprison, W. (2021). Kerjasama guru pai dan orang tua dalam menghadapi pembelajaran selama covid-19. EDUKATIF: Jurnal Ilmu Pendidikan, 3(5), 2319-2335.

Sadiman, A.S. (2011). Media Pendidikan: Pengertian, Pengembangan, Dan Pemanfaatannya. Rajawali Press.

Sapriyah, S. (2019, May). Media Pembelajaran dalam Proses Belajar Mengajar. In Prosiding Seminar Nasional Pendidikan FKIP (Vol. 2, No. 1, pp. 470-477).

Setiarani, S., \& Suchyadi, Y. (2018). Pola Asuh Orang Tua Terhadap Anak Tuna Netra Berprestasi Usia Sekolah Dasar. Jppguseda | Jurnal Pendidikan \& Pengajaran Guru Sekolah Dasar, l(01), 15-18. 
Smart, A. (2010). Anak Cacat Bukan Kiamat Metode Pembelajaran Dan Terapi Anak Berkebutuhan Khusus. Yogyakarta: Kata Hati.

Smith, J. D. (2006). Inklusi sekolah ramah untuk semua. Bandung: Nuansa.

Widjaya, A. (2012). Seluk-Beluk

Tunanetra. Yogyakarta: Java Litera. 